\begin{tabular}{|l|c|c|c|r|}
\hline $\begin{array}{l}\text { Cuadernos de Investigación Geográfica } \\
\text { Geographical Research Letters }\end{array}$ & 2017 & N $^{\circ} 43(2)$ & pp. 449-466 & $\begin{array}{r}\text { ISSN 0211-6820 } \\
\text { eISSN 1697-9540 }\end{array}$ \\
\hline
\end{tabular}

\title{
DEGLACIATION OF THE CORDILLERA OF WESTERN CANADA AT THE END OF THE PLEISTOCENE
}

\section{J.J. CLAGUE}

\author{
Department of Earth Sciences, Simon Fraser University, Burnaby, BC V5A 1S6 Canada.
}

\begin{abstract}
Nearly all of what is now British Columbia and adjacent areas were covered by an ice sheet at the maximum of the Last Glaciation (MIS 2) about 18,000 years ago. By 11,000 years ago, the Cordilleran Ice Sheet had disappeared, a victim of warming climate, eustatic sea-level rise along its western margin, and perhaps a reduction in precipitation. Deglaciation proceeded by frontal retreat at the periphery of the ice sheet and by downwasting, complex frontal retreat, and localized stagnation in its interior areas. The chronology of deglaciation is constrained, albeit with inherent dating errors, by AMS radiocarbon and ${ }^{10} \mathrm{Be}$ surface exposure ages. High-elevation sites at the western margin of the British Columbia Interior Plateau, east of the Coast Mountains, became ice-free between about 15,000 and 12,000 years ago. Ice cover in the southern Coast Mountains was sufficiently extensive during the Younger Dryas Chronozone (12,900-11,700 years ago) that glaciers advanced into low-lying areas north and east of Vancouver. At the same time, however, a labyrinth of dead or dying tongues of glacier ice covered some interior valleys. By 11,000 years ago, ice cover in the Canadian Cordillera was no more extensive than it is today.
\end{abstract}

\section{Deglaciación de la Cordillera Occidental de Canadá a finales del Pleistoceno}

RESUMEN. Casi todo lo que hoy es Columbia Británica y áreas adyacentes estuvieron cubiertas por un manto de hielo durante el máximo de la Última Glaciación (MIS 2) hace unos 18.000 años. Hace unos 11.000 años el manto de hielo de la cordillera había desaparecido, víctima del calentamiento climático, el ascenso eustático del nivel del mar en su margen occidental, y quizás una reducción de la precipitación. La deglaciación se produjo por retroceso frontal en la periferia del manto de hielo y por desmantelamiento, retroceso frontal complejo, y estancamiento local en áreas del interior. La cronología de la deglaciación está bien definida, aunque con inherentes errores de datación, mediante radiocarbono por AMS y edades de exposición superficial mediante ${ }^{10} \mathrm{Be}$. Los lugares elevados en el margen occidental de la Llanura Interior de Columbia Británica, al este de las montañas de la Costa, quedó libre de hielo entre 15.000 y 12.000 años BP. La cubierta de hielo en el sur de las Montañas de la Costa fue suficientemente extensa durante el Younger Dryas (12.900-11.700 años BP), de manera que los 
glaciares avanzaron hacia áreas bajas del norte y este de Vancouver. A la vez, sin embargo, un laberinto de lenguas glaciares muertas o moribundas cubrieron algunos valles del interior. Hace 11.000 años la masa de hielo en la Cordillera de Canadá no era más extensa de lo que es hoy.

Key words: Deglaciation, Cordilleran Ice Sheet, British Columbia, Yukon Territory, Geochronology.

Palabras clave: Deglaciación, Manto de hielo de la Cordillera, Columbia Británica, Territorio del Yukón, Geocronología.

Received: 31 January 2017

Accepted: 1 March 2017

Corresponding author: John J. Clague, Department of Earth Sciences, Simon Fraser University, Burnaby, BC V5A 1S6 Canada E-mail address: jclague@sfu.ca

\section{Introduction}

British Columbia is located within the mid-latitudes of the Northern Hemisphere adjacent to the North Pacific Ocean, which is the main moisture source for present and past glaciers in northwest North America. This mountainous region is dominated by northwest-trending ranges, rolling plateaus, and, on the west, by coastal lowlands. The highest peaks in British Columbia are in the St. Elias Mountains (Mount Fairweather, $4671 \mathrm{~m}$ a.s.1.), the southern Coast Mountains (Mount Waddington, $4016 \mathrm{~m}$ a.s.1.), and the southern Rocky Mountains (Mount Robson, 3954 m a.s.1.). The high mountains of British Columbia today support valley and cirque glaciers and some ice caps. Glaciers presently cover about $26,000 \mathrm{~km}^{2}$, or 3 percent, of British Columbia (Clague et al., 2011), which is close to the minimum for the entire Quaternary Period.

A large ice sheet (the Cordilleran Ice Sheet) blanketed much of Northwest North America several times during the past 3 million years (Clague, 1989; Jackson and Clague, 1991). At its maximum, the Cordilleran Ice Sheet and its satellite glaciers covered almost all of British Columbia, as well as southern Yukon Territory, southern Alaska, and northern Washington, Idaho, and Montana (Fig. 1). Glaciers in several bordering mountain ranges were semi-independent of the Cordilleran Ice Sheet, even at times of maximum ice cover.

The last Cordilleran Ice Sheet attained its maximum size in British Columbia, where it was up to $1900 \mathrm{~km}$ long, $900 \mathrm{~km}$ wide, and up to $3000 \mathrm{~m}$ thick (Wilson et al., 1958). At the Last Glacial Maximum, this ice sheet probably had the shape of an elongate dish, with gentle slopes in the interior region and steeper slopes at the periphery. It may have resembled the present-day Greenland Ice Sheet at that time. More commonly, the interior of the ice sheet had an irregular undulating surface, with several ice divides that shifted through time. These ice divides were subordinate to the main divide along the axis of the Coast Mountains. Although there may have been localized areas of cold ice at the base of the Cordilleran Ice Sheet, especially at high elevations where the ice was relatively thin, the ice sheet was dominantly warm-based (Lian and Hicock, 2000). 


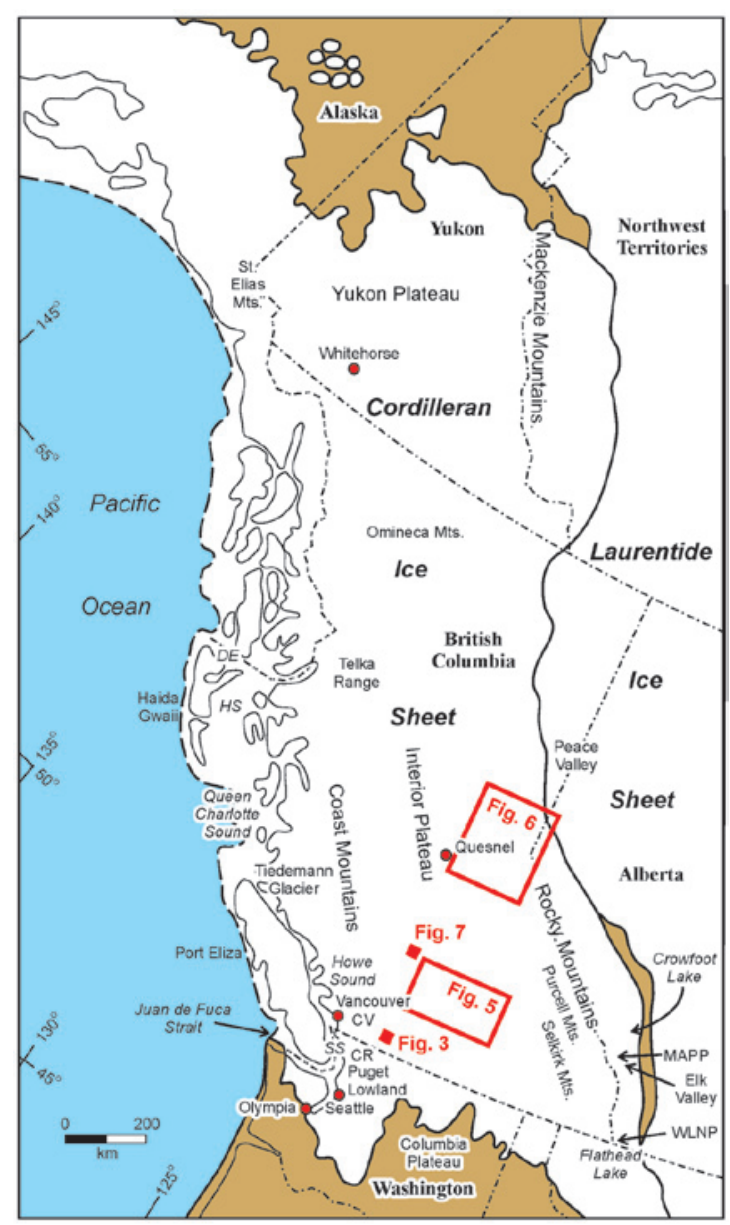

Figure 1. The fully developed Cordilleran Ice Sheet and its satellite glaciers at the maximum of the last glaciation, about 18,000 years ago (modified from Clague, 1989). Also shown are places referred to in the text; $C R$-Cascade Range, CV-Coquitlam Valley, DE-Dixon Entrance, HS - Hecate Strait; MAPP - Mount Assiniboine Provincial Park, WLNP Waterton Lakes National Park.

Outlet glaciers of the ice sheet streamed down fjords and valleys in the coastal mountains of British Columbia and covered large areas of the Pacific continental shelf (Clague et al., 1982; Barrie and Conway, 1999), parts of which were subaerially exposed due to eustatically lowered sea levels of the Last Glaciation. Some lobes at the western margin of the ice sheet extended to the shelf edge, where they calved into deep water. Glaciers issuing from the southern Coast Mountains and the mountains on Vancouver Island coalesced over the northern Salish Sea (Strait of Georgia) to produce a great outlet glacier that flowed south along Puget Sound in Washington State (Waitt and Thorson, 1983). Glaciers streaming down valleys farther east likewise terminated as large lobes in eastern Washington, Idaho, and Montana (Waitt and Thorson, 1983). 
To the east, glaciers flowed from the British Columbia interior and the Rocky Mountains, and locally coalesced with the Laurentide Ice Sheet over the Rocky Mountain Foothills (Clague, 1989; Dyke, 2004; Bednarski and Smith, 2007; Atkinson et al., 2016; Huntley et al., 2017). These ice masses, however, joined only briefly at the maximum of the last glaciation 18,000 years ago (Jackson et al., 1999). At other times, an ice-free zone existed between Cordilleran glaciers and the Laurentide ice sheet to the east.

\section{Pattern of deglaciation}

Deglaciation of British Columbia, which began shortly after 18,000 years ago and was complete 6000 years later (Clague, 1981), was characterized by frontal retreat along the outer margins of the ice sheet and by downwasting, frontal retreat, and local stagnation in the interior of British Columbia (Fulton, 1967, 1991). The western part of the ice sheet, grounded on the British Columbia continental shelf, became unstable first and retreated back to fjord heads and valleys (Luternauer et al., 1989; Barrie and Conway, 1999). Frontal retreat also occurred elsewhere along the outer margins of the ice sheet, for example in northern Washington, Idaho, and western Montana (Thorson, 1980; Booth, 1987; Smith, 2004) and southern Yukon Territory (Jackson et al., 1991; Bond et al., 2014).

A somewhat different pattern of deglaciation has been documented for some areas of low and moderate relief nearer the center of the ice sheet, notably southern British Columbia. Deglaciation in these areas occurred by downwasting, retreat, and stagnation, and proceeded through four stages, conceptualized by Fulton $(1967,1969,1991)$ as follows: (1) active ice phase-regional flow continued but diminished as ice thinned; (2) transitional upland phase-the highest uplands became ice free but regional flow continued in valleys; (3) stagnant ice phase-ice was confined to valleys but was still thick enough to flow; and (4) dead ice phase-ice tongues in valleys thinned to the point that they no longer flowed (Fig. 2). Geomorphic evidence for this pattern of deglaciation is compelling: sequences of successively lower and younger glacial lake shorelines and sediments in some valleys; flights of ice-marginal channels extending over vertical ranges of hundreds of meters; cirques that were free of ice before adjacent valleys (Fig. 3); and ice-stagnation features at a range of elevations and in a variety of geomorphological positions (Fig. 4).

However, even in interior regions dominated by 'top-down' wasting, the ice sheet retreated back toward high montane source areas, mainly the Coast Mountains (Clague, 1987; Huntley and Broster, 1997; Perkins et al., 2013; Perkins and Brennand, 2015; Brennand and Perkins, 2017). For example, the active front of the ice sheet in southern British Columbia retreated to the north-northwest (Fig. 5; Fulton, 1967); and in eastcentral British Columbia, it retreated west and west-southwest back towards the Coast Mountains (Fig. 6; Margold et al., 2013).

As ice thinned over the British Columbia interior, a dynamic subglacial hydrologic system developed and matured (Burke et al., 2012a). Channelized subglacial flow discharged toward ice margins and into rapidly evolving ice-marginal and proglacial lakes. Other evidence for this subglacial hydrologic system includes single and anabranching eskers, and channels carved into bedrock on the Interior Plateau (Burke et al., 2012b).

The first areas to become ice-free were those along the western periphery of the ice sheet (Clague, 1989). Deglaciation of the continental shelf was rapid, triggered in 


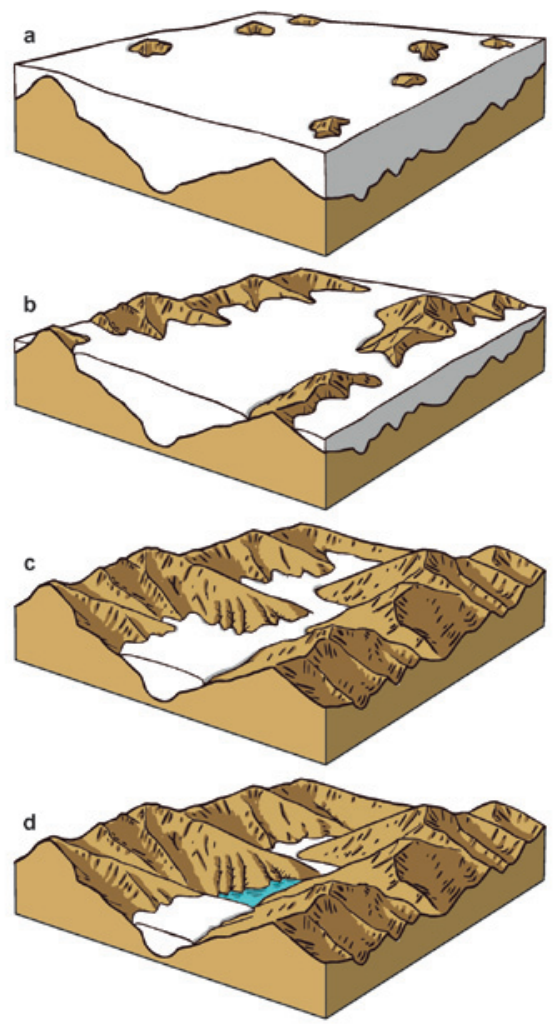

Figure 2. Conceptual model of deglaciation in areas of low to moderate relief in the British Columbia interior (after Fulton, 1967). a) Active ice phase, b) transitional upland phase, c) stagnant ice phase, $d$ ) dead ice phase.

part by eustatic sea-level rise and in part by the collapse of the proglacial forebulge centered beneath Haida Gwaii, Dixon Entrance, Queen Charlotte Sound, and western Vancouver Island (Clague, 1983; Barrie and Conway, 2002; Hetherington et al., 2004). Warming of North Pacific Ocean waters, into which the western margin of the ice sheet calved, rapidly cleared ice from the continental shelf. Rapid easterly retreat of the ice sheet toward the mainland coast drew down the ice surface in the Coast Mountains, bringing it increasingly under influence of the warmer climate of that time.

The Puget lobe retreated northward in contact with a series of glacial lakes situated on glacio-isostatically depressed crust beneath the southern Salish Sea (Thorson, 1989). Coincidentally, the Juan de Fuca lobe, which occupied Juan de Fuca Strait between Olympic Peninsula and southern Vancouver Island, rapidly retreated eastward towards the Salish Sea. No longer buttressed by the Juan de Fuca lobe, the Puget lobe rapidly calved northward, and its most northerly glacial lake drained into Juan de Fuca Strait. Soon thereafter, a large calving embayment opened in the northern Salish Sea, driving glaciers back to the heads of fjords in the southern Coast Mountains (Armstrong, 1981; Huntley et al., 2001). 


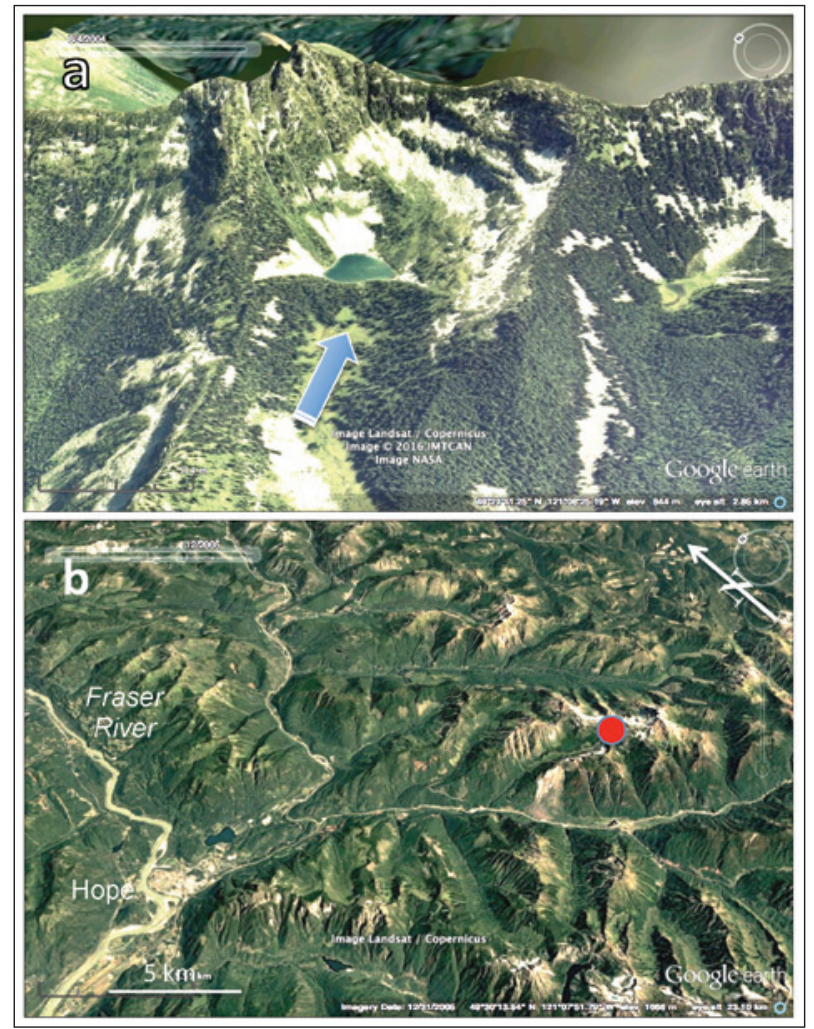

Figure 3. a) Google Earth image of a cirque in the southern Cascade Mountains, southeast of Hope, British Columbia, that became ice-free before the adjacent valley floor. A moraine constructed at the margin of the ice tongue that filled the valley crosses the mouth of the cirque (arrow). b) Image showing the location of the cirque (red dot). See Figure 1 for location in British Columbia.

Other marginal areas of the ice sheet were also deglaciated early. The Okanagan and Purcell Trench lobes, which terminated on the Columbia Plateau in northwest Washington State, began to retreat soon after the Last Glacial Maximum. On the east, outlet glaciers flowing eastward down large valleys that extend across the Rocky Mountains, as well as independent glaciers sourced in the higher parts of that range, retreated back towards the Rocky Mountain front. The outlet glacier in Peace River valley receded in contact with glacial Lake Peace, which was impounded to the east by the Laurentide Ice Sheet (Mathews, 1978, 1980; Catto et al., 1996; Hickin et al., 2015). Similarly, to the north, lobes of the Cordilleran Ice Sheet lying on the southern Yukon Plateau retreated towards mountain ranges to the east, south, and west, locally in contact with glacial lakes trapped in valleys.

With continued thinning, the Cordilleran Ice Sheet disintegrated into a labyrinth of tongues of dead or dying ice and active glaciers flowing mainly from the Coast Mountains. Active ice probably persisted longest in high mountain valleys, but these remnant glaciers may have coexisted with large masses of dead ice in some areas of the British Columbia interior. 


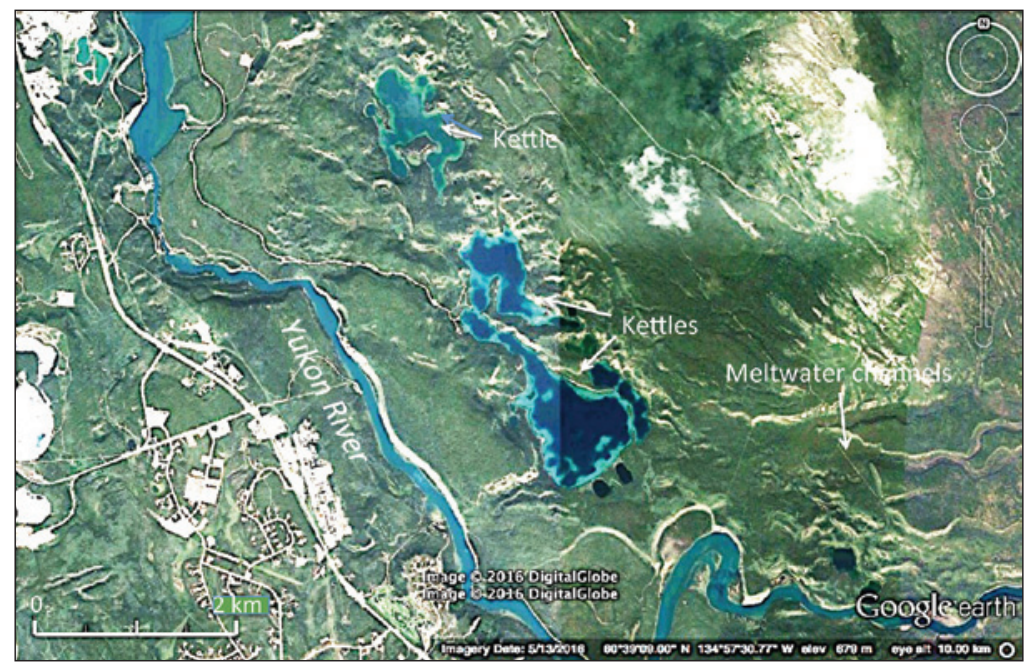

Figure 4. Ice-stagnation landforms in the Yukon River valley near Whitehorse, Yukon (Google Earth image).

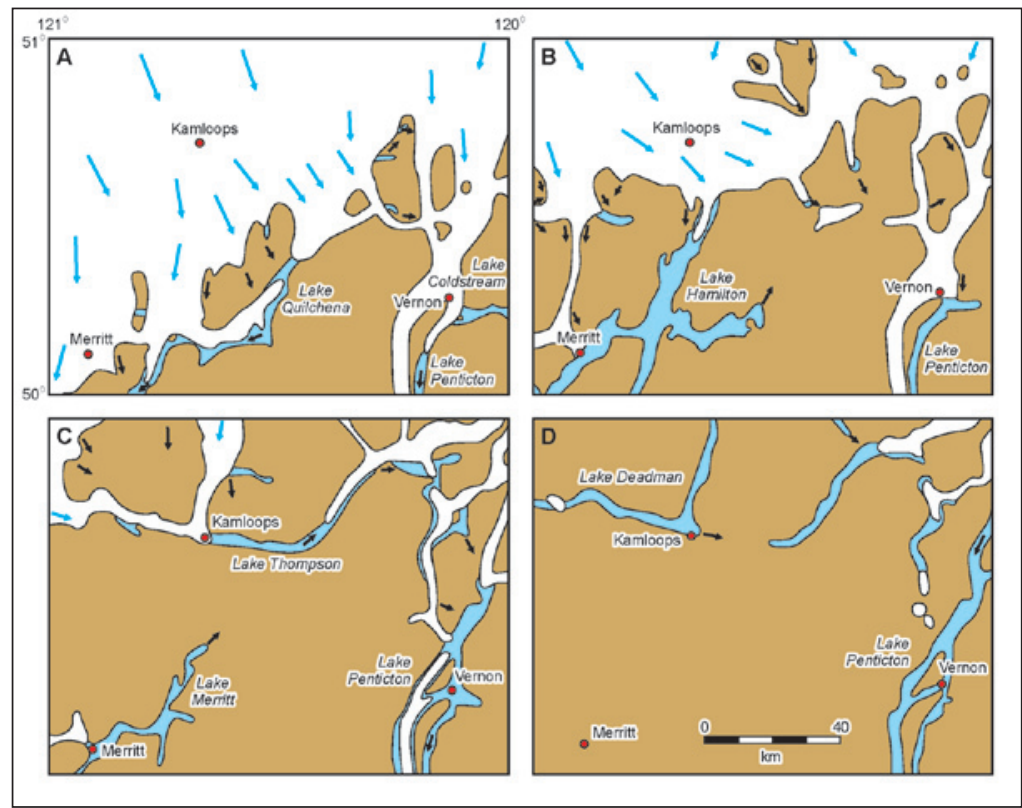

Figure 5. Sequential pattern of ice retreat in south-central British Columbia (adapted from Fulton, 1969). The ice sheet downwasted and retreated to the north-northwest. Tongues of stagnant and dead ice separated from the active ice front and became stranded in interior valleys. These ice tongues dammed glacial lakes. The sequence of events depicted in the four panels probably span about 500 years or less. Blue arrows are generalized ice-flow directions. Black arrows show meltwater and lake overflow directions. See Figure 1 for location in British Columbia. 


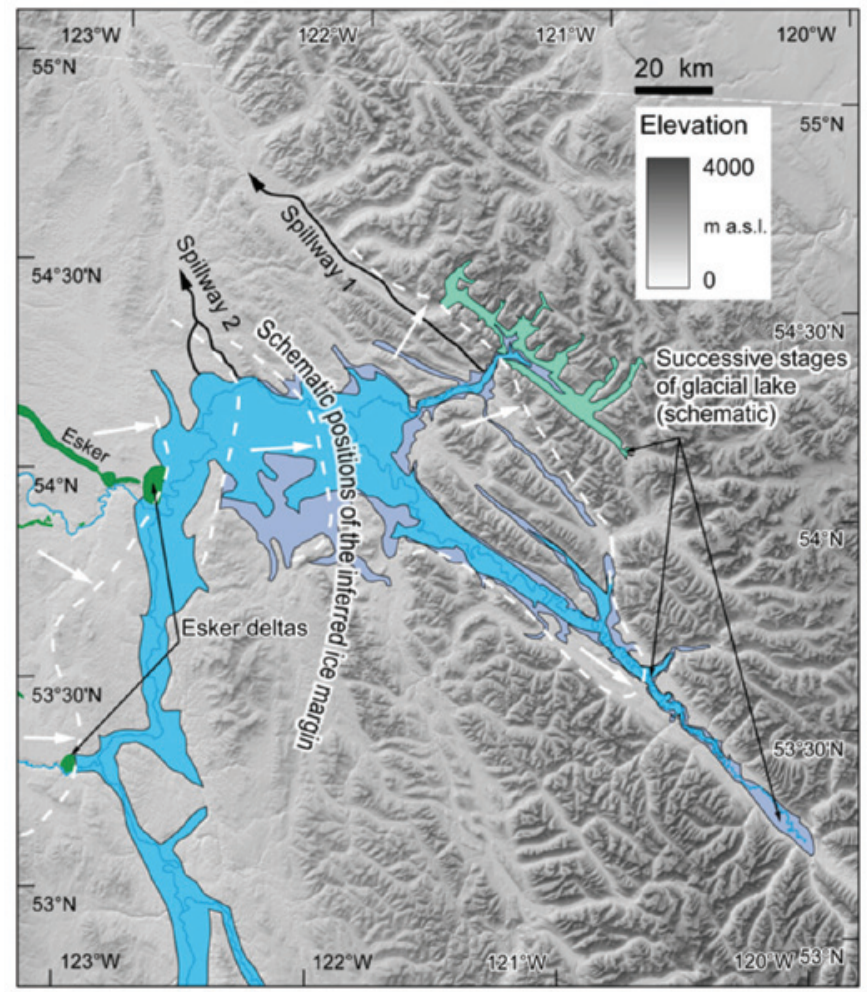

Figure 6. Sequential pattern of ice retreat envisioned for part of central British Columbia (Margold et al. 2013, their Fig. 13). In this region, the ice sheet downwasted and retreated to the west. Early lakes impounded against the retreating ice front in west-draining valleys of the Rocky Mountains were succeeded by a series of rapidly evolving lakes over the central Interior Plateau. See Figure 1 for location in British Columbia.

Disintegration of the Cordilleran Ice Sheet was interrupted repeatedly by glacier readvances (Alley and Chatwin, 1979; Clague, 1984, 1989; Clague et al., 1997; Friele and Clague, 2002a, 2002b; Kovanen, 2002; Lakeman et al., 2008). Most re-advances affected relatively small areas and may not have been synchronous from one region to another. Minor resurgences in the central Fraser Lowland east of Vancouver are particularly well documented (Armstrong, 1981; Clague et al., 1997; Kovanen, 2002). At least one of these advances happened during or before the Older Dryas interval; another may have happened during an intra-Allerød cold interval; and a third likely dates to the Younger Dryas interval. Two of these events are also recorded in Chilliwack River valley, where a lobe of the Cordilleran Ice Sheet in nearby Fraser Lowland advanced at least twice over forest in the lower reach of the valley and impounded a lake upstream (Saunders et al., 1987). Similarly, Friele and Clague (2002a, 2002b) provided stratigraphic and geomorphic evidence for an advance of a lobe of the Cordilleran Ice sheet in the Cheakamus River valley north of Vancouver during the Younger Dryas chronozone. The glacier advanced over terrain that had earlier become vegetated and 
reached as far south as the present head of Howe Sound. An implication of this study, as well as those of Clague et al. (1997) and Kovanen (2002) in Fraser Lowland, is that the southern Coast Mountains had a large cover of ice, with some glaciers reaching to sea level as late as 13,000 years ago (see below).

\section{Chronology of deglaciation}

The Cordilleran Ice Sheet disappeared over a period of about 6000 years at the end of the Pleistocene Epoch. Given the rapidity of its demise, together with inherent errors in radiocarbon and surface exposure ages pertinent to deglaciation, the exact ages of events remain uncertain. Nevertheless, the radiometric ages, viewed as a whole, have enabled researchers to constrain the chronology of deglaciation (Table 1).

Until about a decade ago, this chronology was based entirely on radiocarbon ages, initially radiometric ${ }^{14} \mathrm{C}$ ages and later accelerator mass spectrometry ${ }^{14} \mathrm{C}$ ages (Table 1 ; Clague, 1981). Unfortunately, but unavoidably, nearly all deglacial radiocarbon ages are only 'one-sided' limiting ages for the time of local deglaciation. Remains of plants that became established after specific localities became ice-free yield minimum ages for the time of local deglaciation, and detrital wood and other plant remains recovered from till yield maximum ages that are not necessarily close to the time of deglaciation. Nevertheless, some localities have provided radiocarbon ages that are thought to closely approximate the time of deglaciation, and these are summarized below. The best of these sites are in coastal British Columbia and Washington State; in contrast, there are few localities in much of the interior region of the former ice sheet that have yielded plant and animal fossils that closely delimit the time of deglaciation.

\subsection{Early retreat}

Several localities near the periphery of the former Cordilleran ice sheet have provided information on the time of initial deglaciation. The Puget lobe of the Cordilleran Ice Sheet reached its maximum extent near present-day Olympia, Washington, about 16,000-16,500 years ago, and began to retreat soon thereafter (Porter and Swanson, 1998; Troost, 2017). Ice-proximal lacustrine and deltaic sediments in valleys at the west front of the North Cascade Range have yielded abundant plant fossils that closely date the maximum extent of the Puget lobe and its initial retreat. Similarly, lobes terminating on the northern Columbia Plateau east of the Cascade Range were retreating northward when Glacier Peak last erupted, approximately 13,400-13,700 years ago (Porter, 1978). Hofmann and Hendrix (2010) recovered a pine needle from varved sediments in Flathead Lake in northern Montana, well inside the maximum limit of the Purcell Trench lobe; it yielded a calibrated radiocarbon age of about 14,200 years BP. At the west margin of the ice sheet, the Cape Ball site on Haida Gwaii (former Queen Charlotte Islands) yielded remains of plants that became established immediately after the site was deglaciated 19,000 years ago (Warner et al., 1982). This record is consistent with a peak of ice-rafted debris in a deep-sea core from the eastern North Pacific that places maximum ice cover on the north coast of British Columbia just before 19,000 years ago (Blaise et al. 1990; Clague et al., 2004). Port Eliza cave on the northwest coast of Vancouver Island was first blocked by glacier ice about 


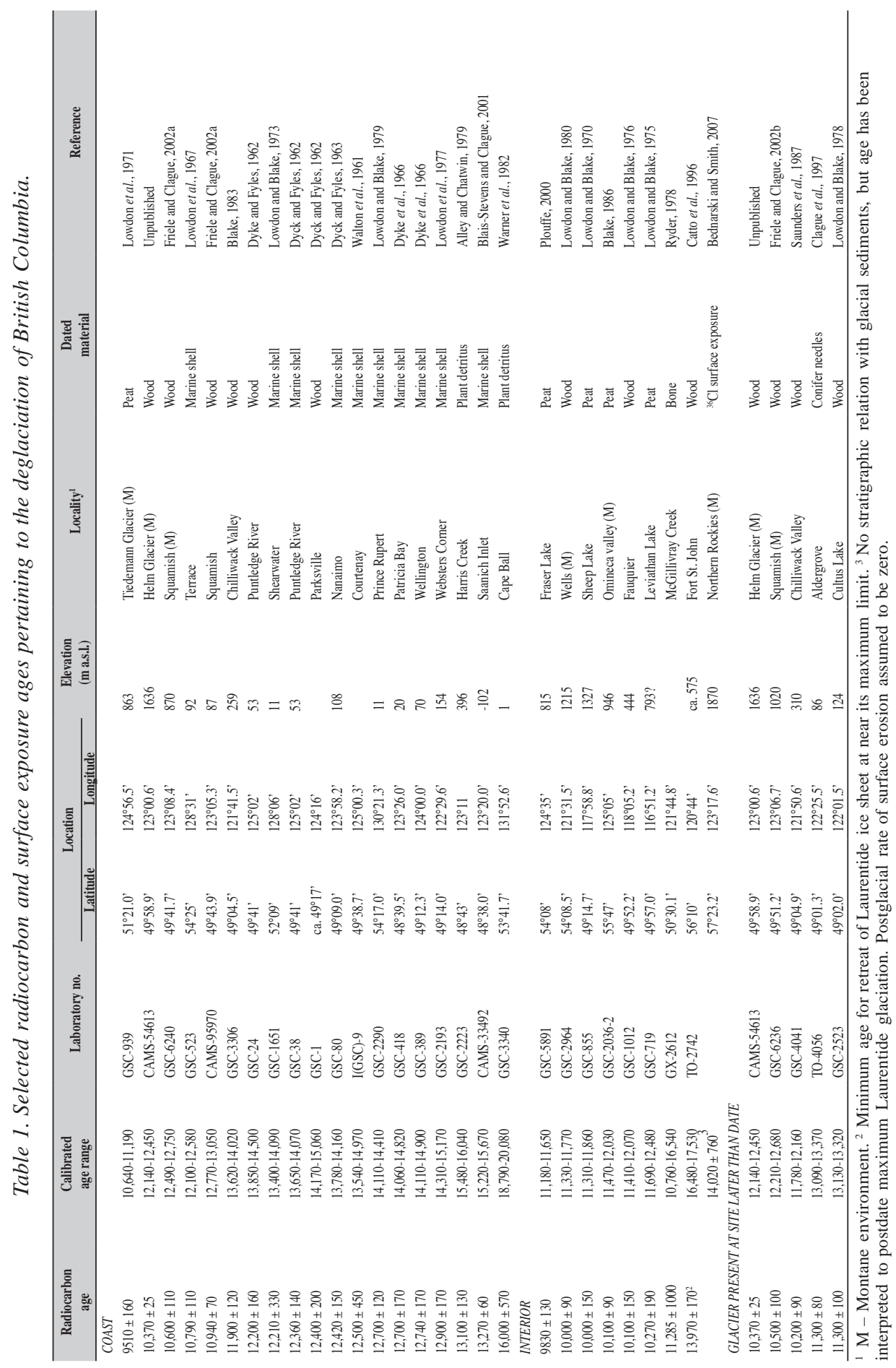


19,000 years ago (Ward et al., 2003; Al-Suwaidi et al., 2006). Ice reached the edge of the British Columbia continental shelf 17,000 years ago and began to retreat about 16,200 years ago, based on a rapid reduction in ice-rafted debris in deep-sea cores to the west (Cosma et al., 2008).

The chronology of retreat of the east margin of the Cordilleran Ice Sheet remains poorly constrained. The paucity of radiocarbon ages in that region and the complex interplay between semi-independent alpine Rocky Mountain glaciers and lobes of interior Cordilleran ice that reached to or beyond the Rocky Mountain front make it difficult to reliably date glacier retreat. Relevant radiocarbon ages are also scarce in the northern sector of the ice sheet in Yukon Territory.

With the advent and development of surface exposure dating techniques in the 1990s, it became possible to date erratics and glacially polished bedrock surfaces, and thus obtain estimates of the time elapsed since deglaciation. However, application of these techniques requires some assumptions and corrections, which inevitably lead to uncertainties in the derived ages (Gosse and Phillips, 2001). Errors are similar to, or larger than, those associated with calibrated radiocarbon ages. Nevertheless, several studies have reported ${ }^{10} \mathrm{Be}$ surface exposure ages of erratics, boulders on moraines, and bedrock in British Columbia and Yukon. These studies have helped constrain times at which high-elevation upland surfaces in the Cordillera became ice-free. Two recent examples are summarized below.

Margold et al. (2014) presented ${ }^{10} \mathrm{Be}$ exposure ages from two high-elevation sites in southern and central British Columbia. They sampled granodiorite erratics at elevations of about 2100-2200 m a.s.l. in the Marble Range (Figure 7) and 1600-1800 m a.s.l. in the Telkwa Range, both at the western margin of the British Columbia Interior Plateau. The locations of the erratics and their relations to meltwater channels ensured that the resulting ${ }^{10} \mathrm{Be}$ ages date ice sheet deglaciation and not the retreat of local montane glaciers. The two areas emerged above the surface of the Cordilleran Ice Sheet as its divide migrated westward from the Interior Plateau to the axis of the Coast Mountains. Two of the four samples from the summit area of the Marble Range yielded apparent exposure ages of $14.0 \pm 0.7$ and $15.2 \pm 0.8 \mathrm{ka}$ (Figure 7). These ages are 800-2000 years younger than the well established age of ca. 16,000 years for the initiation of retreat of the Puget lobe in Washington State; they are another 700 years younger if a snow-shielding correction to their uncertainty-weighted mean age is applied. The other two samples yielded much older apparent exposure ages, which Margold et al. (2014) attributed to the presence of inherited isotopes. Four samples collected from the summit area of the Telkwa Range in the Hazelton Mountains yielded exposure ages of $10.1 \pm 0.6,10.2 \pm 0.7,10.4 \pm 0.5$, and $11.5 \pm 1.1 \mathrm{ka}$. Significant present-day snow cover at the sample sites in the Telkwa Range introduces a large uncertainty in these exposure ages. A snow-shielding correction based on present-day snow cover data increases the uncertainty-weighted mean exposure age of the erratics to $12.4 \pm 0.7 \mathrm{ka}$, consistent with deglacial radiocarbon ages from areas near sea level to the west. Taken together, the exposure ages from the two high-elevation sites show a thinning of the southern portion of the Cordilleran Ice Sheet shortly after the Late Glacial Maximum and, perhaps, persistence of a remnant mountain ice cap in the central Coast Mountains until near the end of the Pleistocene. 


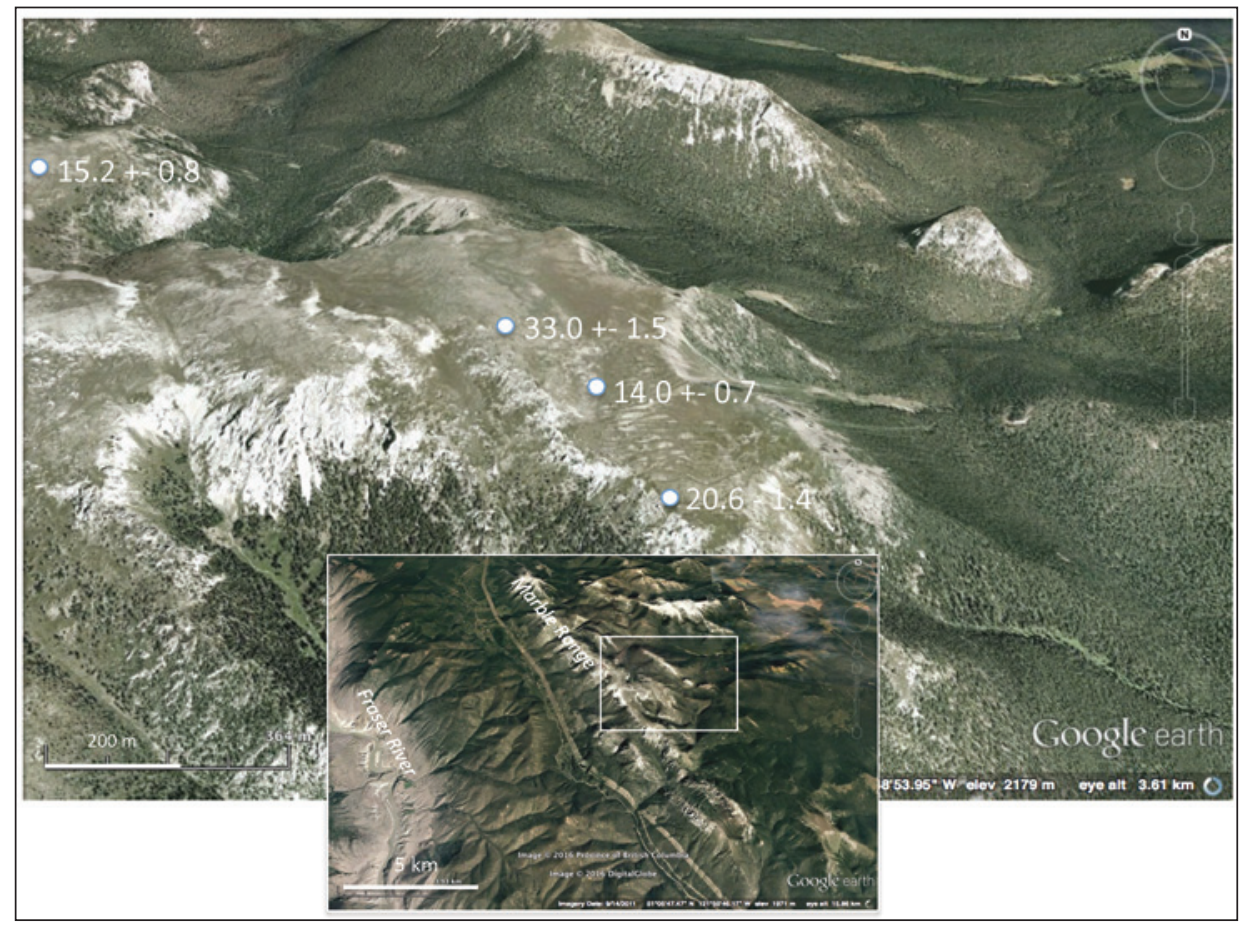

Figure 7. ${ }^{10}$ Be surface exposure ages ( $\left.k a\right)$ from high elevations in the Marble Range, British Columbia. See Figure 1 for location in British Columbia.

\subsection{The final demise of the ice sheet}

The time of deglaciation of most plateaus and valleys of the southern and central interior of the Canadian Cordillera is broadly constrained to the period 13,000-11,500 years ago. Most radiocarbon ages from this region do not closely delimit the time of deglaciation (Fulton, 1971; Clague, 1981), but several are telling. Wood recovered from a placer mine east of Quesnel in central British Columbia, for example, yielded a radiocarbon age of $10,000 \pm 90{ }^{14} \mathrm{C}$ yr BP, indicating that this area was ice-free sometime between 11,300 and 11,800 years ago. Basal peat recovered from a bog directly outside the outermost lateral moraine of Tiedemann Glacier, one of the largest glaciers in the southern Coast Mountains, returned an age of $9510 \pm 150{ }^{14} \mathrm{C}$ yr BP (Fulton, 1971; Lowdon, et al. 1971), showing that glaciers in the highest part of this mountain range were no more extensive than today before 10,400 years ago, and possibly before 11,400 years ago. Viewed in total, these ages indicate that the Cordilleran Ice Sheet has disappeared, and ice cover was not more extensive than today, before 11,000 years ago. It follows that the present drainage network in British Columbia was established by the beginning of the Holocene.

Glacier ice loss during the Bølling-Allerød interval exposed many high-elevation cirques in the British Columbia before adjacent valley floors. Lakeman et al. (2008) presented evidence that the Cordilleran Ice Sheet in north-central British Columbia thinned and in some areas transformed into a labyrinth of dead or dying ice tongues in valleys. 
During the Younger Dryas, however, alpine glaciers advanced downvalley and built moraines or coalesced with dead ice masses at lower elevations. Their hypothesis accords with a conceptual model of ice sheet decay in which some high-elevation uplands and cirques became ice-free before valley bottoms (Fulton, 1991; Margold et al., 2014).

Menounos et al. (2017) reported $75{ }^{10} \mathrm{Be}$ surface exposure ages on bedrock and boulders associated with lateral and end moraines at 26 locations in high mountains of British Columbia and Yukon Territory. At some sites, they also obtained radiocarbon ages from lakes impounded by the moraines or from till. The ${ }^{10} \mathrm{Be}$ dataset includes samples from eight valley and eight cirque moraines. Three older moraines have a combined median age $13.9 \pm 1.1 \mathrm{ka}$, whereas a younger group of 12 moraines has a median age of $11.4 \pm 1.6 \mathrm{ka}$. Combined, the median age for all 15 moraines is $11.7 \pm 2.5 \mathrm{ka}$. Menounos et al. (2017) linked the advances that built the two sets of high-elevation valley and cirque moraines to the Bølling-Allerød and Younger Dryas cold periods.

The work of Menounos et al. (2017) is supported by a body of other research on moraines just outside Little Ice Age moraines in British Columbia and Alberta. Basal sediments in a lake $0.5 \mathrm{~km}$ downstream of one such moraine in the southern Coast Mountains yielded a radiocarbon age of $9680 \pm 40{ }^{14} \mathrm{C}$ yr BP $(11,200-10,800$ years ago), which is a minimum for the age of the advance that constructed the moraine (Minkus, 2006). Similarly, glaciers either formed anew or advanced from cirques in the southern Rocky Mountains during the Crowfoot Advance near the end of the Pleistocene (Luckman and Osborn, 1979; Osborn and Gerloff, 1997). Reasoner et al. (1994) correlated construction of the type Crowfoot moraine to deposition of sediment in adjacent Crowfoot Lake, which they dated to 13,000-11,500 years ago. The moraine thus was built during the Younger Dryas. Correlative moraines located short distances beyond, or partly covered by, Little Ice Age moraines are found in the national parks in the southern Rocky Mountains of Alberta (Luckman and Osborn, 1979), Waterton Lakes National Park (Osborn, 1985), upper Elk Valley in the British Columbia Rocky Mountains (Ferguson, 1978), Mount Assiniboine Provincial Park (Menounos et al., 2009), and the Purcell and Selkirk mountains (Figure 1; Menounos et al., 2009). An advance of cirque and valley glaciers during the Younger Dryas is consistent with paleoecological data (Mathewes et al., 1993; Taylor et al., 2014) that indicate a return to cold conditions along British Columbia's west coast at that time.

\section{Conclusion}

The last Cordilleran Ice Sheet achieved its maximum extent about 18,000 years ago, when it covered an area of over 1.5 million $\mathrm{km}^{2}$, including nearly all of present-day British Columbia, southern Yukon Territory, and parts of Alberta, Alaska, Washington, Idaho, and Montana. About 6000 years later, the ice sheet had disappeared and ice cover in northwest North America was no more extensive than it is today. Deglaciation was triggered by rapid climate warming, eustatic sea-level rise along the western margin of the ice sheet, and perhaps reduced precipitation due to changes in atmospheric circulation with attendant moisture starvation over the eastern surface of the ice sheet. Deglaciation proceeded by rapid frontal retreat across the British Columbia continental shelf, somewhat slower retreat at the northern and southern limits of the ice sheet, and by complex frontal retreat accompanied by top- 
down wasting and localized stagnation in the British Columbia interior. In some areas, lobes of the decaying ice sheet advanced one or more times during the Late Glacial period. Deglaciation was accompanied the formation, rapid evolution, and draining of glacial lakes. All glacial lakes had drained, and the present-day drainage system was in place, by the start of the Holocene.

\section{References}

Alley, N.F., Chatwin, S.C. 1979. Late Pleistocene history and geomorphology, southwestern Vancouver Island, British Columbia. Canadian Journal of Earth Sciences 16, 1645-1657. http://doi.org/10.1139/e79-154.

Al-Suwaidi, M., Ward, B.C., Wilson, M.C., Hebda, R.J., Nagorsen, D.W., Marshall, D., et al. 2006. Late Wisconsinan Port Eliza cave deposits and their implications for human coastal migration, Vancouver Island, Canada. Geoarcheology 21, 307-332. http://doi.org/10.1002/gea.20106.

Armstrong, J.E. 1981. Post-Vashon Wisconsin Glaciation, Fraser Lowland, British Columbia. Geological Survey of Canada Bulletin 322.

Atkinson, N., Pawley, S., Utting, D.J. 2016. Flow-pattern evolution of the Laurentide and Cordilleran ice sheets across west-central Alberta, Canada: implications for ice sheet growth, retreat and dynamics during the last glacial cycle. Journal of Quaternary Science 31, 753-768. http://doi. org/10.1002/jqs.2901.

Barrie, J.V., Conway, K.W. 1999. Late Quaternary glaciation and postglacial stratigraphy of the northern Pacific margin of Canada. Quaternary Research 51, 113-123. http://doi.org/10.1006/ qres.1998.2021.

Barrie, J.V., Conway, K.W. 2002. Rapid sea-level change and coastal evolution on the Pacific margin of Canada. Sedimentary Geology 150, 171-183. http://doi.org/10.1016/S0037-0738(01)002743.

Bednarski, J.M., Smith, I.R. 2007. Laurentide and montane glaciation along the Rocky Mountain Foothills of northeastern British Columbia. Canadian Journal of Earth Sciences 44, 445-457. http://doi.org/10.1139/e06-095.

Blais-Stevens, A., Clague, J.J. 2001. Paleoseismic signature in late Holocene sediment cores from Saanich Inlet, British Columbia. Marine Geology 175, 131-148. http://doi.org/10.1016/S00253227(01)00132-3

Blaise, B., Clague, J.J., Mathewes, R.W. 1990. Time of maximum late Wisconsinan Glaciation, west coast of Canada. Quaternary Research 47, 140-146. http://doi.org/10.1016/00335894(90)90041-I.

Blake Jr., W. 1983. Geological Survey of Canada Radiocarbon Dates XXIII. Geological Survey of Canada Paper 83-87.

Blake Jr., W. 1986. Geological Survey of Canada Radiocarbon Dates XXV. Geological Survey of Canada Paper 85-87.

Bond, J.D., Ward, B.C., Gosse, J.C. 2014. Late Pleistocene deglaciation of the Cordilleran ice sheet from southwest Yukon; timing, recession rates, and implications. Geological Society of America Abstracts with Program 46 (6), 797.

Booth, D.B. 1987. Timing and processes of deglaciation along the southern margin of the Cordilleran ice sheet. In: W.F. Ruddiman, H.E. Wright (Eds.), North America and Adjacent Oceans During the Last Deglaciation, Geological Society of America, Geology of North America K-3, pp. 71-90.

Brennand, T.A., Perkins, A.J. 2017. The deglacial landscape of the southern Fraser Plateau. In: O. Slaymaker (Ed.), Landscapes and Landforms of Western Canada, Springer International Publishing, Cham, Switzerland, pp. 277-290. 
Burke, M.J., Brennand, T.A., Perkins, A.J. 2012a. Evolution of the subglacial hydrologic system beneath the rapidly decaying Cordilleran Ice Sheet caused by ice-dammed lake drainage: Implications for meltwater-induced ice acceleration. Quaternary Science Reviews 50, 125-140. http://doi.org/10.1016/j.quascirev.2012.07.005.

Burke, M.J., Brennand, T.A., Perkins, A.J. 2012b. Transient subglacial hydrology of a thin ice sheet: Insights from the Chasm esker, British Columbia, Canada. Quaternary Science Reviews 58: 30-55. http://doi.org/10.1016/j.quascirev.2012.09.004

Catto, N.R., Liverman, D.G.E., Bobrowsky, P.T., Rutter, N., Mandryk, C.A.S. 1996. Laurentide, Cordilleran, and Montane glaciation in the western Peace River - Grand Prairie region, Alberta and British Columbia, Canada. Quaternary International 32, 21-32. http://doi. org/10.1016/1040-6182(95)00061-5.

Clague, J.J. 1981. Late Quaternary Geology and Geochronology of British Columbia. Part 2. Summary and Discussion of Radiocarbon-Dated Quaternary History. Geological Survey of Canada Paper 80-35.

Clague, J.J. 1983. Glacio-isostatic effects of the Cordilleran ice sheet, British Columbia, Canada. In: D.E. Smith, A.G. Dawson (Eds.), Shorelines and Isostasy, Academic Press, London, pp. 321-343.

Clague, J.J. 1984. Quaternary Geology and Geomorphology, Smithers-Terrace-Prince Rupert Area, British Columbia. Geological Survey of Canada Memoir 413.

Clague, J.J. 1987. Quaternary stratigraphy and history, Williams Lake, British Columbia. Canadian Journal of Earth Sciences 24, 147-4158.

Clague, J.J. 1989. Cordilleran ice sheet. In Quaternary Geology of Canada and Greenland, R.J. Fulton (ed.), Geological Survey of Canada, Ottawa, ON, pp. 40-43.

Clague, J.J., Mathewes, R.W., Warner, B.G. 1982. Late Quaternary geology of eastern Graham Island, Queen Charlotte Islands, British Columbia. Canadian Journal of Earth Sciences 19, 1786-1795. http://doi.org/10.1139/e82-157.

Clague, J.J., Mathewes, R.W., Guilbault, J.P., Hutchinson, I., Ricketts, B.D. 1997. Pre-Younger Dryas resurgence of the southwestern margin of the Cordilleran ice sheet, British Columbia, Canada. Boreas 26, 261-278. http://doi.org/10.1111/j.1502-3885.1997.tb00855.x.

Clague, J.J., Menounos, B., Wheate, R. 2011. Canadian Rockies and Coast Mountains of Canada. In: V. Singh, P. Singh, U.K. Haritashya (Eds.), Encyclopedia of Snow, Ice and Glaciers, Springer Netherlands, pp. 106-110.

Cosma, T.N., Hendy, I.L., Chang, A.S. 2008. Chronological constraints on Cordilleran Ice Sheet glaciomarine sedimentation from core MD02-2496 off Vancouver Island (Western Canada). Quaternary Science Reviews 27, 941-955. http://doi.org/10.1016/j.quascirev.2008.01.013.

Dyke, A.S. 2004. An outline of North American deglaciation with emphasis on central and northern Canada. Developments in Quaternary Sciences 2, 373-424. http://doi.org/10.1016/S15710866(04)80209-4.

Dyck, W., Fyles, J.G. 1962. Geological Survey of Canada radiocarbon dates I. Radiocarbon 4, 13-26.

Dyck, W., Fyles, J.G. 1963. Geological Survey of Canada radiocarbon dates II. Radiocarbon 5, 39-55.

Dyck, W., Lowdon, J.A., Fyles, J.G., Blake Jr., W. 1966. Geological Survey of Canada radiocarbon dates V. Radiocarbon 8, 96-127.

Friele, P.A., Clague, J.J. 2002a. Readvance of glaciers in the British Columbia Coast Mountains at the end of the last glaciation. Quaternary International 87, 45-58. http://doi.org/10.1016/ S1040-6182(01)00061-1.

Friele, P.A., Clague, J.J. 2002b. Younger Dryas readvance in Squamish River valley, southern Coast Mountains, British Columbia. Quaternary Science Reviews 21, 1925-1933. http://doi. org/10.1016/S0277-3791(02)00081-1. 
Fulton, R.J. 1967. Deglaciation studies in Kamloops Region, an area of moderate relief, British Columbia. Geological Survey of Canada Bulletin 154.

Fulton, R.J. 1969. Glacial Lake History, Southern Interior Plateau, British Columbia. Geological Survey of Canada Paper 69-37.

Fulton, R.J. 1971. Radiocarbon Geochronology of Southern British Columbia. Geological Survey of Canada, Paper 71-37.

Fulton, R.J. 1991. A conceptual model for growth and decay of the Cordilleran Ice Sheet. In: L.E. Jackson, Jr., J.J. Clague (Eds.), The Cordilleran Ice Sheet, Géographie Physique et Quaternaire 45, 281-286.

Gosse, J.C, Phillips, F.M. 2001. Terrestrial in situ cosmogenic nuclides; theory and application. Quaternary Science Reviews 20, 1475-1560. http://doi.org/10.1016/S0277-3791(00)00171-2.

Hetherington, R., Barrie, J.V., Reid, R.G.B., MacLeod, R., Smith, D.J. 2004. Paleogeography, glacially induced crustal displacement, and late Quaternary coastlines on the continental shelf of British Columbia, Canada. Quaternary Science Reviews 23, 295-318. http://doi.org/10.1016/j. quascirev.2003.04.001.

Hickin, A.S., Lian, O.B., Levson, V.M., Cui, Y. 2015. Pattern and chronology of glacial Lake Peace shorelines and implications for isostacy and ice-sheet configuration in northeastern British Columbia, Canada. Boreas 44, 288-304. http://doi.org/10.1111/bor.12110.

Hofmann, M.H., Hendrix, M.S. 2010. Depositional processes and the inferred history of ice-margin retreat associated with the deglaciation of the Cordilleran ice sheet: The sedimentary record from Flathead Lake, northwest Montana, USA. Sedimentary Geology 223, 61-74. http://doi. org/10.1016/j.sedgeo. 2009.10.004.

Huntley, D.H., Broster, B.E. 1997. The Late Wisconsinan deglacial history of the east-central Taseko Lakes area, British Columbia. Canadian Journal of Earth Sciences 34, 1510-1520. http://doi. org/10.1139/e17-123.

Huntley, D.H., Bobrowsky, P.T., Clague, J.J. 2001. Ocean Drilling Program Leg 169S: Surficial geology, stratigraphy and geomorphology of the Saanich Inlet area, southeastern Vancouver Island, British Columbia. Marine Geology 174, 27-41. http://doi.org/10.1016/S00253227(00)00140-7

Huntley, D.H., Hickin, A.S., Lian, O.B. 2017. The pattern and style of deglaciation at the Late Wisconsinan Laurentide and Cordilleran ice sheet limits in northeastern British Columbia. Canadian Journal of Earth Sciences 54, 52-75. http://doi.org/10.1139/cjes-2016-0066.

Jackson, L.E. Jr., Clague, J.J. (Eds.) 1991. The Cordilleran Ice Sheet. Géographie Physique et Quaternaire 45, 261-377.

Jackson, L.E. Jr., Ward, B.C., Duk-Rodkin, A., Hughes, O.H. 1991. The last Cordilleran Ice Sheet in Yukon Territory. In: L.E. Jackson, Jr., J.J.Clague (Eds.), The Cordilleran Ice Sheet, Géographie Physique et Quaternaire 45, 341-354.

Jackson Jr., L.E., Phillips, F.M., Little, E.C. 1999. Cosmogenic ${ }^{36} \mathrm{Cl}$ dating of the maximum limit of the Laurentide ice sheet in southwestern Alberta. Canadian Journal of Earth Sciences 36, 1347-1356. http://doi.org/10.1139/e99-038.

Kovanen, D.J. 2002. Morphologic and stratigraphic evidence for Allerod and Younger Dyras age glacier fluctuations of the Cordilleran Ice Sheet, British Columbia, Canada, and northwest Washington, USA. Boreas 31, 163-184. http://doi.org/10.111/j.1502-3885.2002.tb01064.x.

Lakeman, T.R., Clague, J.J., Menounos, B. 2008. Advance of alpine glaciers during final retreat of the Cordilleran ice sheet in the Finlay River area, northern British Columbia, Canada. Quaternary Research 69, 188-200. http://doi.org/10.1016/j.yqres.2008.01.002.

Lian, O.B., Hicock, S.R. 2000. Thermal conditions beneath parts of the last Cordilleran Ice Sheet near its centre as inferred from subglacial till, associated sediments, and bedrock. Quaternary International 68-71, 147-162. http://doi.org/10.1016/S1040-6182(00)00040-9. 
Lowdon, J.A., Blake Jr., W. 1970. Geological Survey of Canada radiocarbon dates IX. Radiocarbon $12,46-86$.

Lowdon, J.A., Blake Jr., W. 1973. Geological Survey of Canada Radiocarbon Dates XIII. Geological Survey of Canada Paper 73-77.

Lowdon, J.A., Blake Jr., W. 1975. Geological Survey of Canada Radiocarbon Dates XVI. Geological Survey of Canada Paper 75-77.

Lowdon, J.A., Blake Jr., W. 1976. Geological Survey of Canada Radiocarbon Dates XVI. Geological Survey of Canada Paper 76-77.

Lowdon, J.A., Blake Jr., W. 1978. Geological Survey of Canada Radiocarbon Dates XVIII. Geological Survey of Canada Paper 78-87.

Lowdon, J.A., Blake Jr., W. 1979. Geological Survey of Canada Radiocarbon Dates XIX. Geological Survey of Canada Paper 79-87.

Lowdon, J.A., Blake Jr., W. 1980. Geological Survey of Canada Radiocarbon Dates XX. Geological Survey of Canada Paper 80-87.

Lowdon, J.A., Fyles, J.G., Blake Jr., W. 1967. Geological Survey of Canada radiocarbon dates VI. Radiocarbon 9, 156-197.

Lowdon, J.A., Robertson, I.M., Blake, Jr., W. 1971. Geological Survey of Canada radiocarbon dates XI. Radiocarbon 13, 255-324.

Lowdon, J.A., Robertson, I.M., Blake Jr., W. 1977. Geological Survey of Canada Radiocarbon Dates XVII. Geological Survey of Canada Paper 77-7.

Luckman, B.H., Osborn, G.D. 1979. Holocene glacier fluctuations in the middle Canadian Rockies. Quaternary Research 11, 52-77. http://doi.org/10.1016/0033-5894(79)90069-3.

Luternauer, J.L., Clague, J.J., Conway, K.W., Barrie, J. V., Blaise, B., Mathewes, R.W. 1989. Late Pleistocene terrestrial deposits on the continental shelf of western Canada: Evidence for rapid sea-level change at the end of the last glaciation. Geology 17, 357-360.

Margold, M., Jansson, K.N., Kleman, J., Stroeven, A., Clague, J.J. 2013. Retreat pattern of the Cordilleran Ice Sheet in central British Columbia at the end of the last glaciation reconstructed from glacial meltwater landforms. Boreas 42, 830-847. http://doi.org/10.1111/bor.12007.

Margold, M., Stroeven, A.P, Clague, J.J., Heyman, J. 2014. Timing of terminal Pleistocene deglaciation at high elevations in southern and central British Columbia constrained by ${ }^{10}$ Be exposure dating. Quaternary Science Reviews 99, 193-202. http://doi.org/10.1016/j. quascirev.2014.06.027.

Mathewes, R.W., Heusser, L.E., Patterson, R.T. 1993. Evidence for a Younger Dryas-like cooling event on the British Columbia coast. Geology 21, 101-104.

Mathews, W.H. 1978. Quaternary Stratigraphy and Geomorphology of Charlie Lake (94-A) MapArea, British Columbia. Geological Survey of Canada Paper 76-20.

Mathews, W.H. 1980. Retreat of the Last Ice Sheets in Northeastern British Columbia and Adjacent Alberta. Geological Survey of Canada Bulletin 331.

Menounos, B., Osborn, G., Clague, J.J., Luckman, B.H. 2009. Latest Pleistocene and Holocene glacier fluctuations in western Canada. Quaternary Science Reviews 28, 2049-2074. http://doi. org/10.1016/j.quascirev.2008.10.018.

Menounos, B., Goehring, B.M., Osborn, G., Margold, M., Ward, B., Bond, J., Clarke, G.K.C., Clague, J.J., Lakeman, T., Koch, J., Schaefer, J., Caffee, M.W., Gosse, J., Stroeven, A.P., Seguinot, J., Heyman, J. 2017. Widespread mass loss of the Cordilleran Ice Sheet signals climate deterioration at the Pleistocene Transition. In review.

Minkus, R.S. 2006. Evidence of Latest Pleistocene Glacier Advance in the Southern Coast Mountains, British Columbia, Canada. M.Sc. thesis, University of Calgary, Calgary, AB.

Osborn, G.D. 1985. Holocene tephrostratigraphy and glacial fluctuations in Waterton Lakes and Glacier national parks, Alberta and Montana. Canadian Journal of Earth Sciences 22, 10931101. http://doi.org/10.1139/e85-111. 
Osborn, G.D., Gerloff, L. 1997. Latest Pleistocene and early Holocene fluctuations of glaciers in the Canadian and northern American Rockies. Quaternary International 38/39, 7-19. http://doi. org/10.1016/S1040-6182(96)00026-2.

Perkins, A.J., Brennand, T.A. 2015. Refining the pattern and style of Cordilleran Ice Sheet retreat: Palaeogeography, evolution and implications of lateglacial ice-dammed lake systems on the southern Fraser Plateau, British Columbia, Canada. Boreas 44, 319-342.http://doi.org/10.1111/ bor. 12100 .

Perkins, A.J.,Brennand, T.A.,Burke, M.J.2013. Genesis of an esker-like ridge over the southern Fraser Plateau, British Columbia: Implications for paleo-ice sheet reconstruction based on geomorphic inversion. Geomorphology 190, 27-39. http://doi.org/10.1016/j.geomprh.2013.02.005.

Plouffe, A. 2000. Quaternary Geology of the Fort Fraser and Manson River Map Areas, Central British Columbia. Geological Survey of Canada Bulletin 554.

Porter, S.C. 1978. Glacier Peak tephra in the north Cascade Range, Washington: Stratigraphy, distribution, and relationship to Lateglacial events. Quaternary Research 10, 30-41. http://doi. org/10.1016/0033-5894(78)90011-X.

Porter, S.C., Swanson, T.W. 1998. Radiocarbon age constraints on rates of advance and retreat of the Puget Lobe of the Cordilleran ice sheet during the last glaciation. Quaternary Research 50 , 205-213. http://doi.org/10.1006/qres.1998.2004.

Reasoner, M.A., Osborn, G., Rutter, N.W. 1994. Age of the Crowfoot advance in the Canadian Rocky Mountains: A glacial event coeval with the Younger Dryas oscillation. Geology 22, 439-442.

Ryder, J.M. 1978. Geomorphology and late Quaternary history of the Lillooet area. In: A. Stryd, S.R. Lawhead (Eds.), Report of the Lillooet Archaeological Project. Number 1. Introduction and Setting, National Museum of Man, Mercury Series, Archaeological Survey of Canada Paper 73, pp. 56-67.

Saunders, I.R., Clague, J.J., Roberts, M.C. 1987. Deglaciation of Chilliwack River valley, British Columbia. Canadian Journal of Earth Sciences 24, 915-923. http://doi.org/10.1139/e87-089.

Smith, L.N. 2004. Late Pleistocene stratigraphy and implications for deglaciation and subglacial processes of the Flathead Lobe of the Cordilleran Ice Sheet, Flathead Valley, Montana, USA. Sedimentary Geology 165, 295-332. http://doi.org/10.1016/sedgeo.2003.11.013.

Taylor, M.A., Hendy, I.L., Pak, D.K. 2014. Deglacial ocean warming and marine margin retreat of the Cordilleran Ice Sheet in the North Pacific Ocean. Earth and Planetary Science Letters 403, 89-98. http://doi.org/10.1016/epsl.2014.06.026.

Thorson, R.M. 1980. Ice-sheet glaciation of the Puget lowland, Washington, during the Vashon Stade (Late Pleistocene). Quaternary Research 13, 303-321. http://doi.org/10.1016/00335894(80)90059-9.

Thorson, R.M. 1989. Glacio-isostatic response of the Puget Sound area, Washington. Geological Society of America Bulletin 101, 1163-1174.

Waitt Jr., R.B., Thorson, R.M. 1983. The Cordilleran ice sheet in Washington, Idaho, and Montana. In: S.C. Porter (Ed.), Late-Quaternary Environments of the United States, Vol. 1, The Late Pleistocene, University of Minnesota Press, Minneapolis, MN, pp. 53-70.

Walton, A., Trautman, M.A., Friend, J.P. 1961. Isotopes, Inc. radiocarbon measurements I. Radiocarbon 3, 47-59.

Ward, B.C., Wilson, M.C., Nagorsen, D.W., Nelson, D.E., Driver, J.C., Wigen, B. 2003. Port Eliza cave: North American west coast interstadial environment and implications for human migrations. Quaternary Science Reviews 22, 1383-1388. http://doi.org/10.1016/S0277-3791(03)00092-1.

Warner, B.G., Mathewes, R.W., Clague, J.J. 1982. Ice-free conditions on the Queen Charlotte Islands, British Columbia, at the height of late Wisconsin glaciation. Science 218, 675-677. http://doi.org/10.1126/science.218.4573.675.

Wilson, J.T., Falconer, G., Mathews, W.H., Prest, V.K. (Compilers) 1958. Glacial Map of Canada. Geological Association of Canada, Toronto, ON. 